\title{
First record of the entomopathogenic protist, Mattesia dispora (Neogregarinorida: Lipotrophidae) of the Mediterranean flour moth, Ephestia kuehniella Zeller (Lepidoptera: Pyralidae) in Turkey
}

\author{
Mustafa Yaman ${ }^{1 *}$, Kâbire Funda Acar ${ }^{2}$ and Renate Radek ${ }^{3}$
}

\begin{abstract}
The present study is the first record of a natural neogregarine infection of Ephestia kuehniella Zeller (Lepidoptera: Pyralidae) in Turkey. The infection occurs in the fat body and hemolymph of the larvae. Typical fresh navicular oocysts of the pathogen were 12.1-16.2 $\mu \mathrm{m}$ in length and 5.9-8.5 in width $(n=50)$. Oocysts stained with Giemsa stain measured 11.7-14.2 $\mu \mathrm{m}$ in length and 5.9-8.5 $\mu \mathrm{m}$ in width. Polar plugs were recognizable using light and electron microscopy. The oocyst wall is quite thick, measuring 460 to $560 \mathrm{~nm}$. Each oocyst contains 8 sporozoites. The described neogregarine has typical characteristics of members of the genus Mattesia (Family Lipotrophidaeorder Neogregarinorida) and shows similarities with Mattesia dispora in morphological and ultrastructural characteristics. The occurrence of the pathogen in different life stages of E. kuehniella was also studied. Total infection was observed as $66.98 \%$ in the investigated samples. The pathogen caused different infection levels in the larvae, pupae, and adults of the E. kuehniella, 57.06, 85, and 3.17\%, respectively.
\end{abstract}

Keywords: Biological control, Ephestia kuehniella, Neogregarine, Mattesia dispora, Turkey

The Mediterranean flour moth, Ephestia kuehniella Zeller, is generally considered one of the most destructive stored-product insect pests worldwide (Sedlacek et al. 1995). It damages stored products such as flour, grains, and dry nuts and causes serious economic losses (Azizoglu et al. 2011a). Microbial insecticides have a considerable potential for controlling insect pests of stored products (Dales, 1994). There are numerous researches on biology, damage, and chemical or ecological protection concerning E. kuehniella (Öztürk et al. 2008 and Azizoglu et al. 2011b). However, entomopathogens naturally occurring in its populations have not been yet investigated in Turkey. In this study, occurrence and infection levels of the

\footnotetext{
* Correspondence: muyaman@hotmail.com

'Department of Biology, Faculty of Arts and Science, Bolu Abant Izzet Baysal University, 14030 Bolu, Turkey

Full list of author information is available at the end of the article
}

neogregarine pathogen on the larvae, pupae, and adults of E. kuehniella were studied to document natural suppressing potential of this pathogen in E. kuehniella populations.

\section{Material and methods}

Samples of 63 adults, 20 pupae, and 538 larvae of $E$. kuehniella were randomly collected during a period of 2 years, 2012 and 2013. First insect collections were obtained from two provinces, Trabzon and Rize in Turkey. Collected samples were transferred to the laboratory and reared till dissection. After macroscopic examination, they were dissected in Ringer's solution and wet smears were prepared. Host fat body, malpighian tubules, gut epithelium, and hemolymph were examined for the presence of oocyts of the neogregarine pathogen under a light microscope at $\times 400-1000$ magnification (Yaman 2004 and Yaman 2007). When 
an infection with the oocysts of the neogregarine pathogen was observed, a part of the material was used for the preparation of Giemsa-stained smears. For this, the slides were air-dried and fixed with methanol, then stained with freshly prepared 5\% solution of Giemsa stain and re-examined under the microscope by using the oil immersion lens. The oocysts detected by the light microscopy were measured and photographed using a microscope with a digital camera and Soft Imaging System. Another specimens were used for preparing samples for scanning (SEM) and transmission electron microscopy (TEM) studies using previously reported techniques (Yaman 2012, Yaman and Radek 2005, 2012).

\section{Results and discussion}

Dissected larvae revealed infections with pathogens. Fat body and hemolymph of the larvae were full of oocysts (Figs. 1 and 2). The oocysts were navicular in shape and possessed plugs at the two poles (Figs. 2 and 3). Typical fresh navicular oocysts of the pathogen were $14.23 \pm 0.85(12.14-16.18) \mu \mathrm{m}$ in length and $7.63 \pm 0.71(5.89-8.49) \mu \mathrm{m}$ in width $(n=50)$. Oocysts stained with Giemsa stain (Fig. 3) measured $12.88 \pm$ $0.67(11.70-14.18) \mu \mathrm{m}$ in length and $6.58 \pm 0.46$ (5.89-8.49) $\mu \mathrm{m}$ in width. Polar plugs were recognizable by light and electron microscopy (Figs. 3, 4 , and 5). The oocyst wall was quite thick, measuring 460 to $560 \mathrm{~nm}$. Each oocyst contained 8 sporozoites

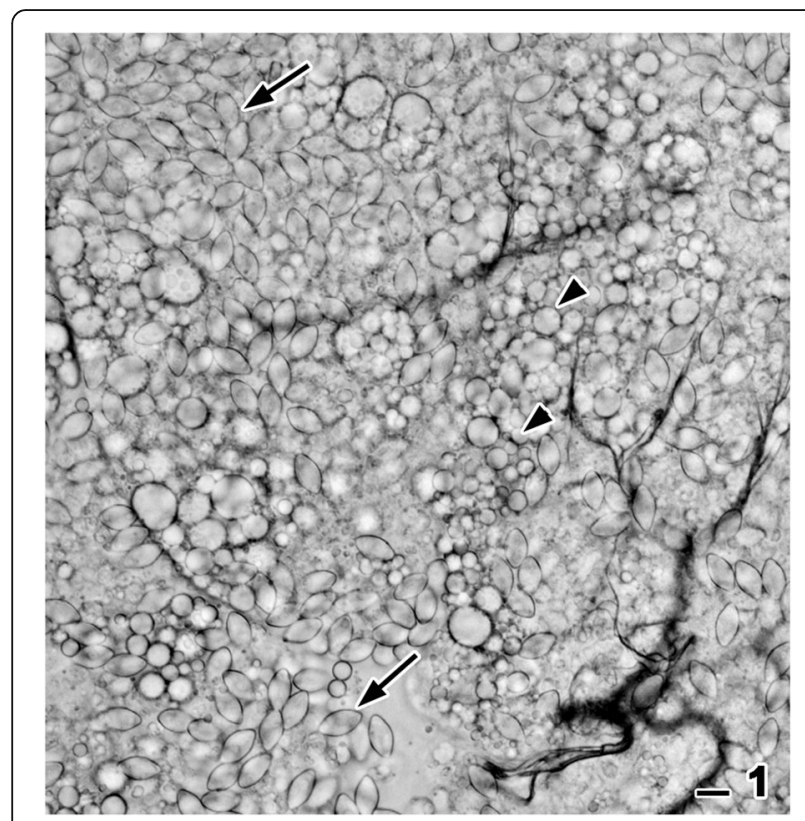

Fig. 1 Fresh oocysts of Mattesia dispora from Ephestia kuehniella. The arrows indicate oocysts and the arrowheads lipid droplets in the heavily infected fat body. Bars, $10 \mu \mathrm{m}$

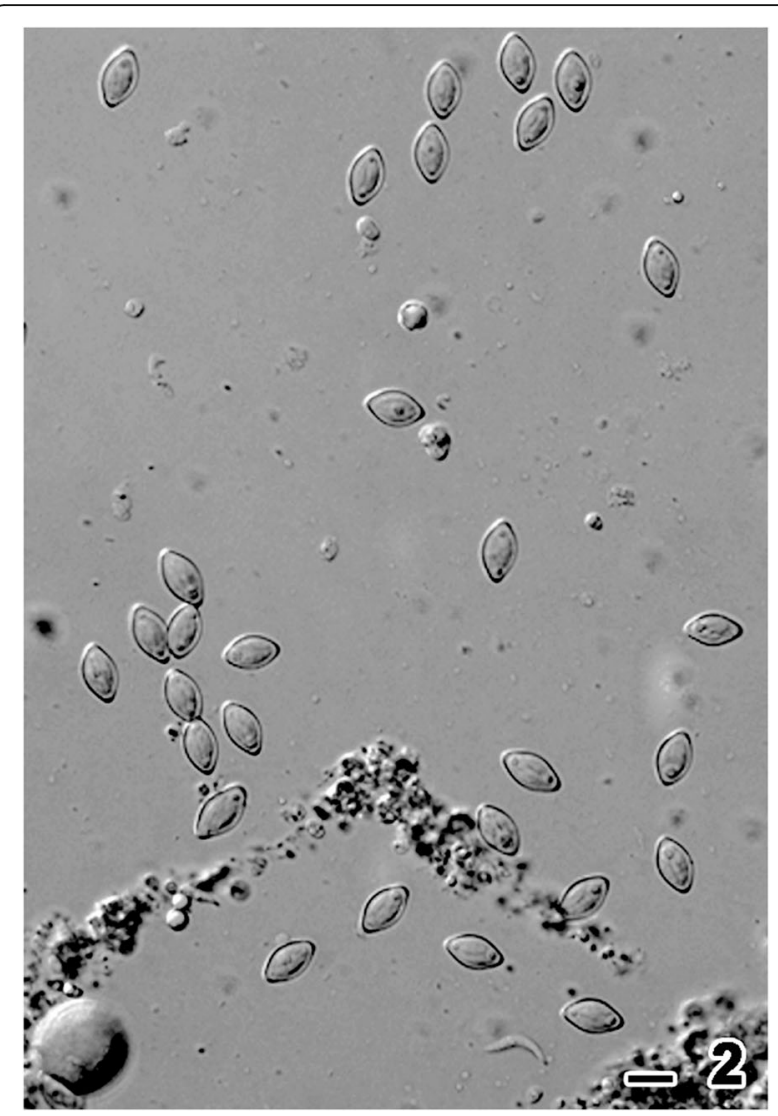

Fig. 2 Fresh oocysts of Mattesia dispora from Ephestia kuehniella. Hemolymph with navicular free oocysts (arrows) including sporozoites and a free sporozoite (arrowhead). Bars, $10 \mu \mathrm{m}$

(Figs. 6 and 7). Infective forms of the neogregarine and the sporozoite were observed freely in the hemolymph (Fig. 2). Occasionally in addition to neogregarine stages, yet undescribed polyhedral inclusion bodies of a nuclear polyhedrosis virus (NPV) were seen on ultrathin sections (Fig. 6).

The results show that the described neogregarine had the typical characteristics of members of the genus Mattesia (Family Lipotrophidae: order Neogregarinorida (Apicomplexa)). It closely resembles Mattesia dispora, which had already been recorded from the host E. kuehniella and was the type species of the genus Mattesia. Morphology and ultrastructural characteristics of the presented neogregarine looked very similar to the life cycle stages depicted by Weiser (1954), Žižka (1978), and Valigurova and Koudela (2006). In detail, the oocyst size matches quite well, being $12.1-16.2 \times 5.9-8.5 \mu \mathrm{m}$ in the present Mattesia, while it was $11.5-14 \times 6.5-7.5 \mu \mathrm{m}$ in Weiser's study (1954). The infection sites (hemolymph and fat body) and the host species (E. kuehniella) were the same in 


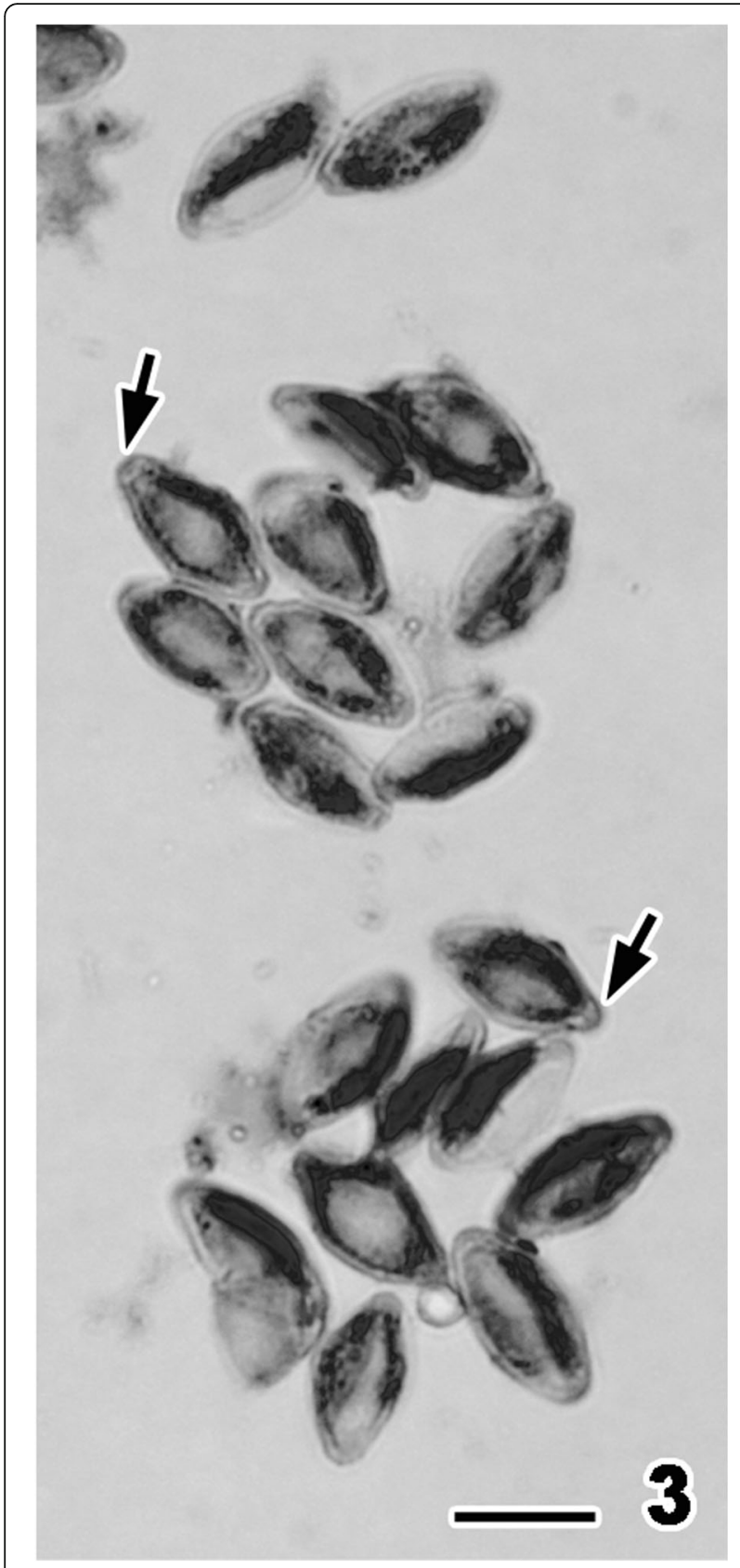

Fig. 3 Giemsa-stained oocysts of Mattesia dispora from Ephestia kuehniella. Giemsa-stained oocysts having polar plugs at each cell pole (arrows). Bars, $10 \mu \mathrm{m}$ the present study and Weiser's (1954) and Valigurova and Koudela's (2006) studies.

In the present study, occurrence of the neogregarine pathogens in the larvae, pupae, and adults of $E$. kuehniella in the laboratory populations was reported for 2 years following each other. Totally, 538 larvae, 20 pupae, and 63 adults were examined for the presence of the neogregarine pathogen, total

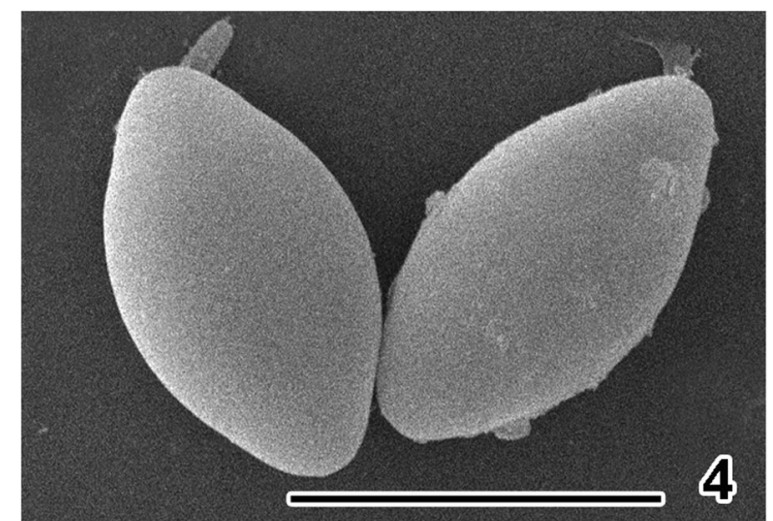

Fig. 4 Oocysts of Mattesia dispora, SEM. Note the navicular oocysts. Bars, $10 \mu \mathrm{m}$

infection occurred as $66.98 \%$. Infection rates were $57.06 \%$ for larvae, $85 \%$ for pupae, and $3.17 \%$ for adults. The results confirm that the infected larvae and pupae could not reach adult stage mostly and the neogregarine pathogen was very effective on both stages.

In Turkey, the microbial control of E. kuehniella has been focused on the spore-forming bacterium, Bacillus thuringiensis (Azizoğlu et al. 2011b). There is no record on naturally occurring entomopathogenic protists of E. kuehniella in Turkey although several protists have been isolated from insects (Yaman et al. 2016 and 2019). The neogregarine presented here was the first one isolated from this pest in Turkey. Although neogregarines were found almost exclusively in insects (Lange and Lord, 2012), until today, there are only three neogregarine

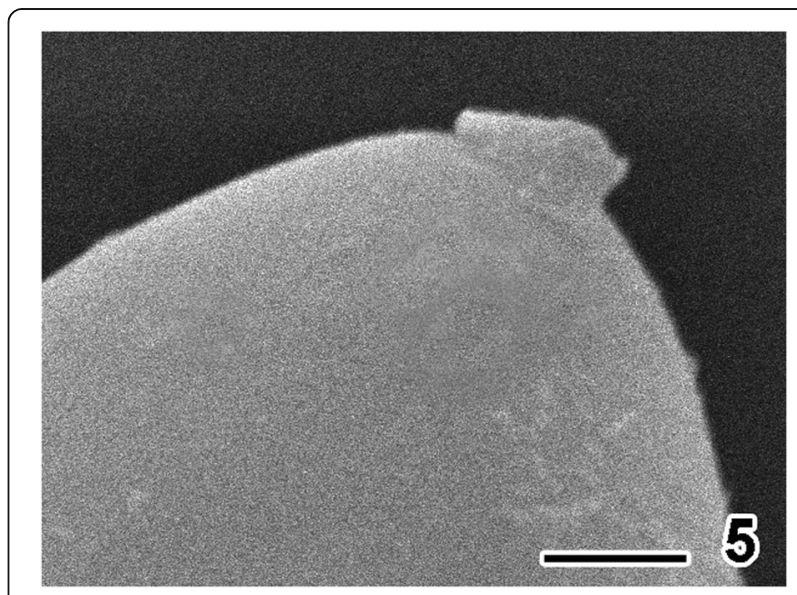

Fig. 5 Oocysts of Mattesia dispora, SEM. Note the protruding polar plug in some oocysts. Bars, 1 mm 


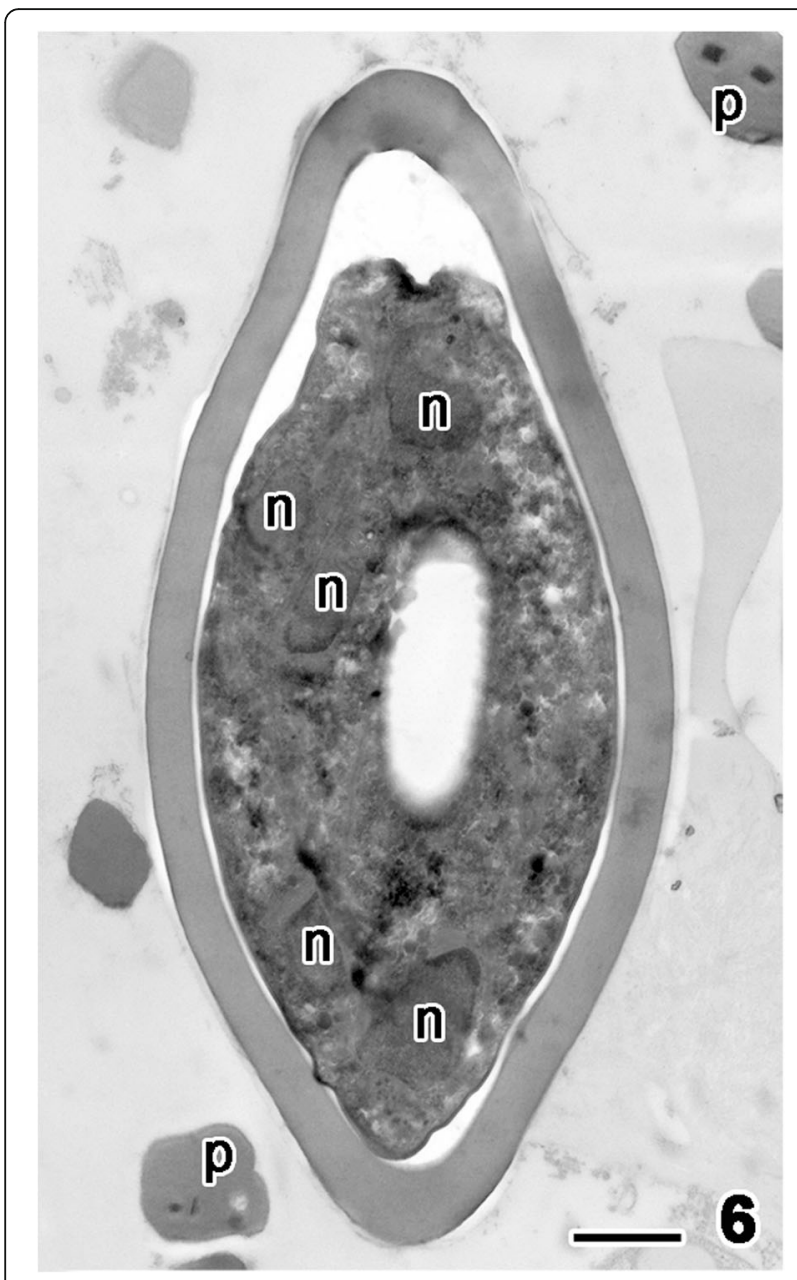

Fig. 6 Mature oocysts of Mattesia dispora, TEM. Longitudinal oocysts including eight sporozoites. n nucleus, ow outer layer of oocyst wall, iw inner layer of oocyst wall. Note the polyhedral inclusion bodies (p) of a nucleopolyhedrosis virus close to the oocyst. Bars, 1 mm records from insects in Turkey, i.e., from Dendroctonus micans (Coleoptera: Curculionidae) (Yaman and Radek 2015) and its specific predator, Rhizophagus grandis (Coleoptera) (Yaman et al. 2012). Two of these neogregarine isolates could be identified as the genus Mattesia (Yaman and Radek 2015), and the third was Menzbieria chalcographi (Yaman et al. 2012). Neogregarines may disperse extensively in the host populations. A high dispersal potential is very important for the biological control of insect pests (Pereira et al., 2002). The genus Mattesia includes several pathogens of major pests, such as the wellstudied $M$. dispora and M. grandis. M. trogodermae has a great potential as a suppressive agent for dermestid beetles, which are also pests of stored products (Lange and Lord 2012).

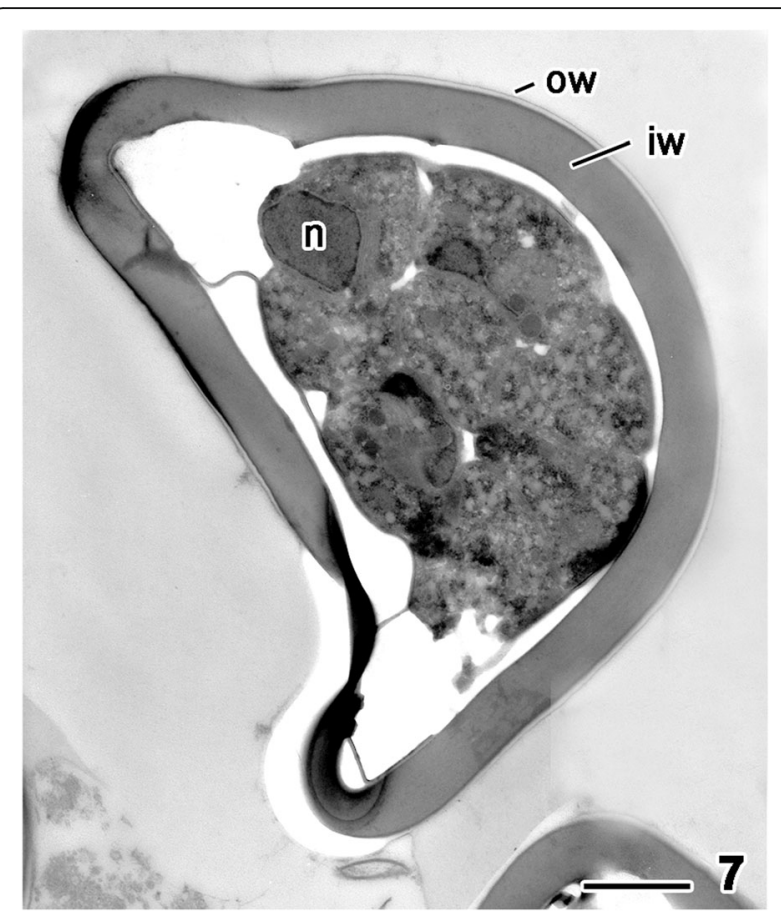

Fig. 7 Mature oocysts of Mattesia dispora, TEM. Cross-sections of oocysts including eight sporozoites. n nucleus, ow outer layer of oocyst wall, iw inner layer of oocyst wall. Bars, $1 \mu \mathrm{m}$

\section{Conclusion}

Laboratory rearing of E. kuehniella for scientific studies should be controlled for pathogens in order to get healthy cultures. Therefore, it is important to know that neogregarines naturally occur in E. kuehniella populations with the high infection in both larvae and pupae and scanning all E. kuehniella cultures for Mattesia infections to get non-infected populations for scientific purposes.

\section{Acknowledgements}

Not applicable

\section{Authors' contributions}

MY collected the insects, identified the neogregarine pathogen, and wrote the manuscript. KBF collected and dissected the insects. RR identified the neogregarine pathogen and wrote the manuscript. All authors read and approved the final manuscript.

\section{Funding}

Not applicable

\section{Availability of data and materials}

All datasets are presented in the main manuscript.

Ethics approval and consent to participate

Not applicable

\section{Consent for publication}

Not applicable

\section{Competing interests}

The authors declare that they have no competing interests. 


\section{Author details}

'Department of Biology, Faculty of Arts and Science, Bolu Abant Izzet Baysal University, 14030 Bolu, Turkey. ${ }^{2}$ Institute of Natural Sciences, Karadeniz Technical University, 61080 Trabzon, Turkey. ${ }^{3}$ Institute of Biology/Zoology, Free University of Berlin, Königin-Luise-Str. 1-3, 14195 Berlin, Germany.

\section{Received: 8 August 2019 Accepted: 9 October 2019}

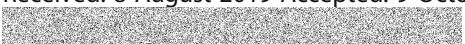

\section{References}

Azizoğlu U, Yılmaz S, Ayvaz A, Karabörklü S, Akbulut M (2011 b) Characterization of local Bacillus thuringiensis isolates and their toxicity to Ephestia kuehniella (Zeller) and Plodia interpunctella (Hubner) larvae. Egyptian J Biol Pest Control 21:143-150

Azizoğlu U, Yılmaz S, Karabörklü S, Ayvaz A (2011a) Ovicidal activity of microwave and UV radiations on Mediterranean flour moth Ephestia kuehniella Zeller, 1879 (Lepidoptera: Pyralidae). Türk Entomol Derg 35:437-446

Dales MJ (1994) Controlling insect pests of stored products using insect growth regulators and insecticides of microbial origin Natural Resources Institute Bulletin 64

Lange CE, Lord JC (2012) Protistan entomopathogens. In: Vega, F.E. and Kaya, H.K. (eds.) Insect pathology (2nd Ed.). Elsevier: Amsterdam, the Netherlands, pp. 367-394

Öztürk F, Açık L, Ayvaz A, Bozdoğan B, Suludere Z (2008) Isolation and characterization of Native Bacillus thuringiensis strains from soil and testing the bioactivity of isolates against Ephestia kuehniella Zeller (Lepidoptera: Pyralidae) larvae. Turk J Biochem 33:202-208.

Pereira RM, Williams DV, Becnel JJ, Oi HD (2002) Yellow-head disease caused by a newly discovered Mattesia sp. in populations of the red imported fire ant, Solenopsis invicta. J Inverteb Pathol 81:45-48

Sedlacek JD, Weston PA, Barney RJ (1995) Lepidoptera and Psocoptera. In: Subramanyam BH, Hagstrum DW (eds) Integrated management of insects in stored products. Marcel Decker, New York, pp 41-70

Valigurova A, Koudela B (2006) Ultrastructural study of developmental stages of Mattesia dispora (Neogregarinorida: Lipotrophidae), a parasite of the flour moth Ephestia kuehniella (Lepidoptera). Eur J Protistol 42:313-323

Weiser J (1954) Stellung der Schizogregarinen der Mehlmotte Ephestia kuehniella. Arch Protistenkd 100:127-142

Yaman M (2004) A newly recorded gregarine parasite of Chaetocnema tibialis (Coleoptera, Chrysomelidae) from Turkey. Turk J Zool 28:95-96

Yaman M (2007) Gregarina typographi Fuchs, a gregarine pathogen of the sixtoothed pine bark beetle, Ips sexdentatus (Boerner) (Coleoptera: Curculionidae, Scolytinae) in Turkey. Turk J Zool 31:359-363

Yaman M (2012) Böcek Patolojisi Atlası (Biyolojik Mücadelede Entomopatojenler (çin). SAGE, Ankara

Yaman M, Algı G, Radek R (2019) Morphological, ultrastructural and molecular identification of a new microsporidian pathogen isolated from Crepidodera aurata (Coleoptera, Chrysomelidae). Turk J Zool 43:407-415

Yaman M, Eroğlu M, Radek R (2016) Occurrence of a microsporidium in the predatory beetle Calosoma sycophanta L. (Coleoptera: Carabidae). Turk J Agric For 40:420-424

Yaman M, Radek R (2005) A new microsporidian parasite record of Phyllotreta undulata (Chrysomelidae, Coleoptera). Turk J Zool 29:67-69

Yaman M, Radek R (2012) Menzbieria chalcographi, a new neogregarine pathogen of the great spruce bark beetle, Dendroctonus micans (Kugelann) (Curculionidae, Scolytionae). Acta Parasitol 53:216-220

Yaman M, Radek R (2015) Mattesia weiseri sp. nov., a new neogregarine (Apicomplexa: Lipotrophidae) pathogen of the great spruce bark beetle, Dendroctonus micans (Coleoptera: Curculionidae, Scolytinae). Parasitol Res 114:2951-2958

Yaman M, Radek R, Linde A (2012) A new neogregarine pathogen of Rhizophagus grandis. North-West J Zool 8:353-357

Žižka Z (1978) Examination of the cyst of Malamoeba locustae and of the spore of Mattesia dispora with the scanning microscope. J Invertebr Pathol 32:119-123

\section{Publisher's Note}

Springer Nature remains neutral with regard to jurisdictional claims in published maps and institutional affiliations.

\section{Submit your manuscript to a SpringerOpen ${ }^{\circ}$ journal and benefit from:}

- Convenient online submission

- Rigorous peer review

- Open access: articles freely available online

- High visibility within the field

- Retaining the copyright to your article

Submit your next manuscript at $\boldsymbol{\nabla}$ springeropen.com 